\title{
Detecting critical choke points for achieving Good Environmental Status in European seas
}

\author{
$\underline{\text { Tavis Potts }}^{1}$, Tim O'Higgins $^{2}, \underline{\text { Ruth Brennan }}^{2}$, Sergio Cinnirella $^{3}$, Urs Steiner Brandt ${ }^{4}, \underline{\text { Juan Luis Suárez de Vivero }}^{5}, \underline{\text { Justus van }}^{\text {Bus }}$
} Beusekom $^{6}$, Tineke A. Troost $^{7}$, Lucille Paltriguera $^{8}$ and Ayse Gunduz Hosgor ${ }^{9}$

\begin{abstract}
Choke points are social, cultural, political, institutional, or psychological obstructions of social-ecological systems that constrain progress toward an environmental objective. Using a soft systems methodology, different types of chokes points were identified in the Outer Hebrides of Scotland, the Baltic, and the North and Mediterranean seas. The choke points were of differing types: cultural and political choke points were identified in Barra and the Mediterranean, respectively, whereas the choke points in the North Sea and Baltic Sea were dependent on differing values toward the mitigation of eutrophication. We conclude with suggestions to identify and address choke points.
\end{abstract}

Key Words: marine policy; Marine Strategy Framework Directive; marine sustainability; soft systems methodology; systems science

\section{INTRODUCTION: WHAT IS A CHOKE POINT?}

Here, we aim to identify choke points constraining the achievement of Good Environmental Status (GEnS) under the Marine Strategy Framework Directive (MSFD; Mee et al. 2008, Long 2011) in the seas of the Northeast Atlantic, the North Sea, the Baltic Sea, and the Mediterranean Sea. We examine the properties of choke points and indicate opportunities for decision makers to address choke points to promote the effective management of European seas.

In the context of military strategy and global trade, choke points have a specific meaning: they are straits with a narrow width that constrain the number of ships passing (Smith et al. 2011, Emmerson and Stevens 2012, Roger 2012). Choke points are of strategic importance because controling them gives a state the ability to constrain the functioning of maritime transport (Noer and Gregory 1996). We apply the concept of choke points by analogy, not to narrow physical straits, but to properties of social ecological systems. We identify choke points as properties of a social-ecological system that constrain progress toward an environmental objective. Choke points are a complex mix of social, political, or psychological obstructions, congestions, or blockages that decrease the power of society to reach its objectives.

For our purposes, the objective under study is the achievement of GEnS for each of the 11 descriptors of marine environmental quality defined in Annex 1 of the MSFD (European Parliament 2008). Social, cultural, and political choke points can involve a conflict or difference in values that acts as an obstacle to the achievement of goals (Brennan and Valcic 2012). Choke points can also be physical and ecosystem properties that constrain action, i.e., the ecological "rules of the game" that cannot be ignored. Addressing choke points may be far more complex than the geopolitical positioning alluded to in the naval analogy. Purely technical fixes to complex social and political phenomena are rare, but not impossible, and are known in the literature as wicked problems (Jentoft and Chuenpagdee 2009). For example, addressing cultural differences between social groups, reforming international mismatches in environmental policy, or addressing the social dimensions of climate change require long-term commitments to engagement, dialog, and action. Identifying institutional choke points involves understanding the layout of the policy system (Bainbridge et al. 2011), where flows of information and resources can be identified. Choke points can scale up to inhibit the implementation of GEnS in transboundary contexts in which political, economic, and socio-cultural interests overlap and occasionally clash. This is the reality in a diverse society such as Europe, whereby nations and communities have common but also differing needs to satisfy their well-being (Mee et al. 2008, Potts et al. 2012).

\section{METHODOLOGY: USING SOFT SYSTEMS ANALYSIS AS A MEANS TO IDENTIFY CHOKE POINTS}

To understand and classify choke points, we deployed the soft systems methodology (SSM) developed by Checkland and Poulter (2006). SSM is a methodology used to structure thinking about, and intervention in, complex and wicked problems (Jentoft and Chuenpagdee 2009, Checkland and Poulter 2010). It engages in systemic modeling of human systems whereby models of "purposeful activity" are developed and compared to real-world situations to facilitate consensus and action (Sørensen et al. 2010). An important distinction of the approach is that it is anchored in understanding reality as the creative construction of human beings (Flood 2010) and works with exploring perspectives and perceptions as the basis of social learning (Checkland and Poulter 2010). SSM has been used in different fields, including agriculture (Flood 2010), urban development (Kasimin and Yusoff 1996), industrial processes (Ngai et al. 2012), and conservation (Cundill et al. 2012).

To explore the concept of choke points, a three-day workshop was conducted during the EU FP7 project "Knowledge-based Sustainable Management for Europe's Seas" in November 2012 in Bruges, Belgium (KnowSeas: http://www.msfd.eu/). Attendees at the workshop included representatives from a range of European universities, marine science institutes, and policy institutes. The workshop was structured around the cycle of the

\footnotetext{
${ }^{1}$ Department of Geography \& Environment, University of Aberdeen, ${ }^{2}$ Scottish Association for Marine Science, ${ }^{3} \mathrm{CNR}$ - Institute of Atmospheric Pollution Research, ${ }^{4}$ University of Southern Denmark, ${ }^{5}$ Universidad de Sevilla, ${ }^{6}$ Helmholtz-Zentrum Geesthacht, ${ }^{7}$ Deltares, ${ }^{8}$ CEFAS, ${ }^{9}$ Middle East Technical University
} 
Fig. 1. Initial soft systems model articulating the interaction of social, cultural, economic, and environmental forces in the delivery of Good Environmental Status.

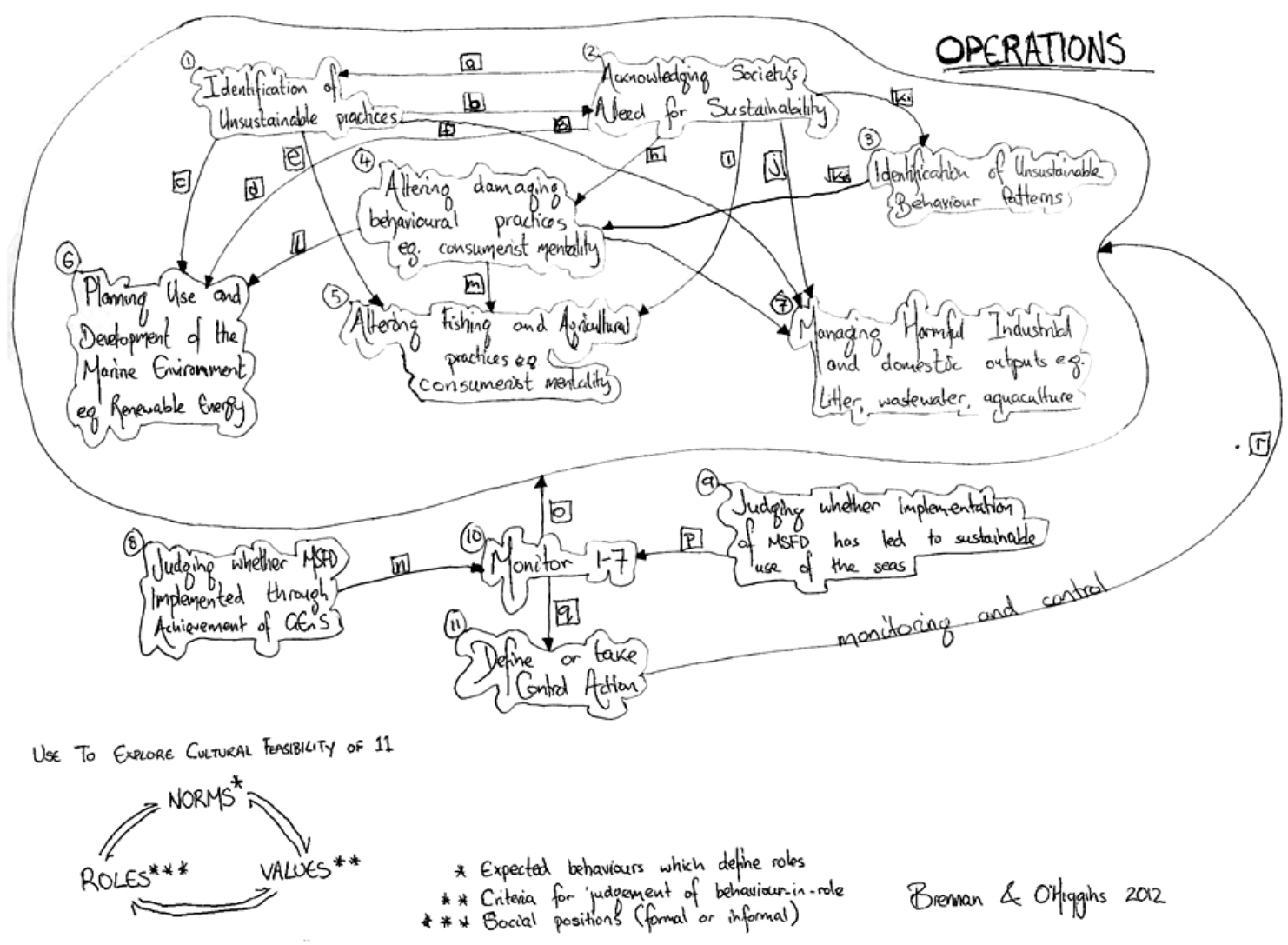

SSM process (Checkland and Poulter 2006, Ngai et al. 2012) and focused on identifying choke points that constrain action on achieving GEnS in Europe. The workshop exercises included:

1. Articulation of the issue that is seen as problematical, and exploring its components and dynamics;

2. Construction of models of activity that are relevant to the situation (termed purposeful activity models by Checkland and Poulter [2006]). Models are informed by developing a root definition, they reflect a worldview, and they are composed of actions that are interlinked;

3. Use of models to question and compare against the real situation. The models structure the discussion and identify culturally, politically, economically, and socially feasible changes; and,

4. Definition of actions that implement acceptable changes and lead to an improvement in the situation.

The articulation of the choke points (stage 1) began with the circulation of a brief and discussion papers that explored concepts of wicked problems (Jentoft and Chuenpagdee 2009), policy networks (Bainbridge et al. 2011), and regional sea governance (Potts et al. 2012) in the context of the MSFD. A draft model was developed (Fig. 1) that supported deliberations on the nature of decision-making in the context of MSFD. The workshop focused on identifying different types of choke points and their characteristics in the context of MSFD. This included discussing the differences between ecological, economic, legal, and psychological choke points. For example, psychological choke points referred to individual and cultural interpretations and worldviews that could block potential action on achieving GEnS. Ecological choke points reflected natural thresholds and limits in ecological systems such as the time lags inherent in nutrient cycling in the Baltic Sea. Economic choke points referred to the cost of activities and policy responses, whereas institutional choke points highlighted organizational complexity and fragmentation undermining the ecosystem approach. Fig. 2 provides examples of working through different classifications of choke points.

In stage 2, we constructed models of "purposeful activity" informed by the development of root definitions. Checkland and Poulter (2006) state that every problematical situation will contain people acting purposefully and with intent to resolve the issue. Building models of this activity can act as a learning device to explore the characteristics of the issue, the differing worldviews of the participants, and the means of resolution. A root definition frames the discussion of purposeful activity. It is a concise description of an activity process that focuses on a transformation, moving a system from one state to another (Ngai 
Fig. 2. Workshop example of working through definitions of the problem situation.

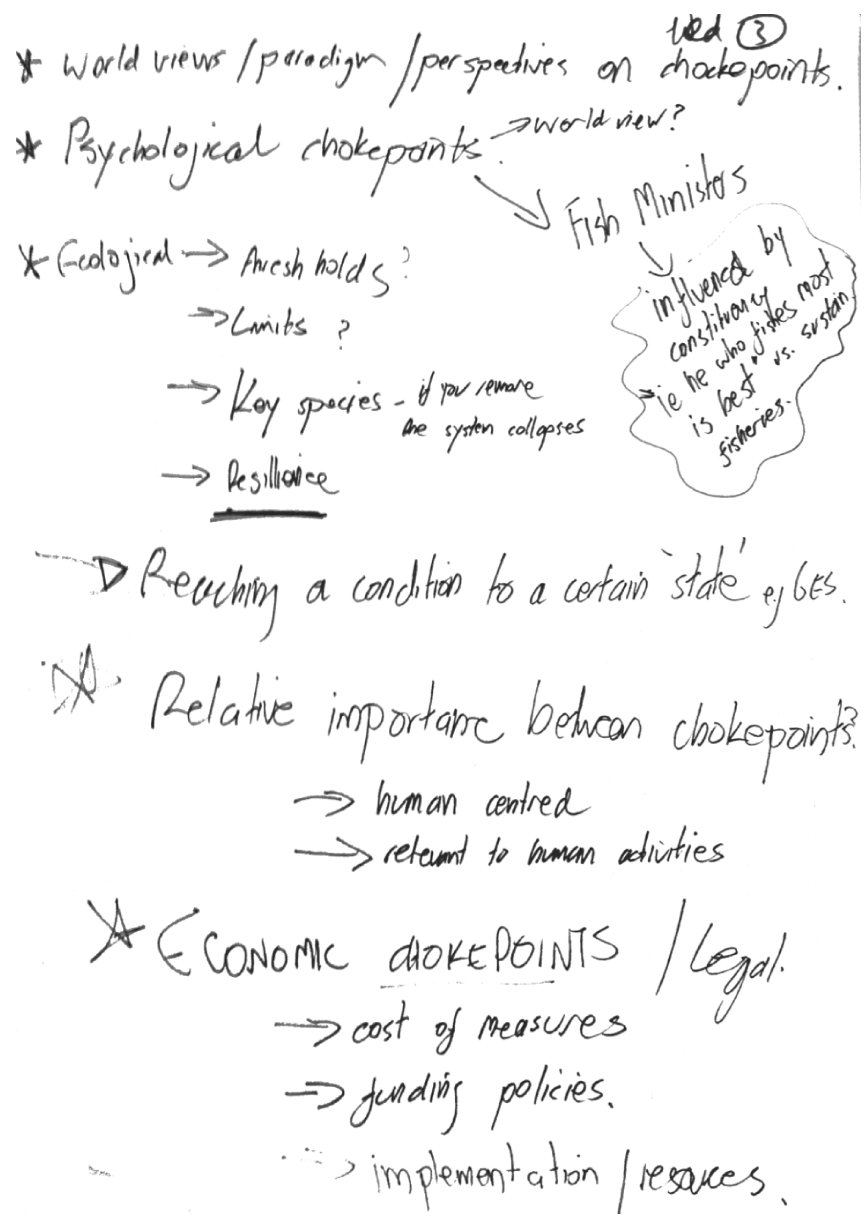

et al. 2012). SSM uses the formula "PQR" to drive the construction of the root definition, whereby an actor does $\mathrm{P}$ via $\mathrm{Q}$ to achieve R (Checkland and Poulter 2006). P specifies the transformation to take place, $\mathrm{Q}$ is how the transformation is to be achieved, and $\mathrm{R}$ is the rationale for the transformation. The working group explored two definitions: a definition for exploring generic choke points, and a worked example using the issue of eutrophication. This process was further informed by a number of definitional exercises under the SSM approach, including the use of CATWOE, a mnemonic technique that checks the rigour of the root definition (Checkland and Poulter 2010) and takes the form of a checklist that aids in defining the model elements. Participants work through the checklist and define: $\mathrm{C}$ (customers), A (actors), $\mathrm{T}$ (transformation process), W (worldview), O (owners), and E (environmental constraints; Checkland and Poulter 2010).

The root definition for the choke points model was agreed upon as: Detecting and addressing critical system choke points through identifying blockages created by time and/or resource constraints in ecological, social, political, and institutional systems to facilitate GEnS of European seas. The root definition for the example of eutrophication was agreed upon as: Moving from eutrophic waters and seas to waters/seas of GEnS by identifying and resolving choke points to reducing nutrient loading to achieve healthy seas.

A model of purposeful activity was developed by participants to guide the case study deliberations. The model (Fig. 3) highlights the issues to be considered, including identifying initial choke points, understanding the conditions underlying choke points, identifying the changes to overcome choke points as well as the actions around those changes, and attribution of actions to actors. Fig. 3 highlights the necessity of monitoring the chokepoint (Checkland and Poulter 2006) and adaptively steering management options. It was critical to remind participants that the models are not attempting to emulate the real world; they are heuristic devices for questioning and comparison. The generic model was compared to a series of European case studies (stage 3 ), and the group deliberated about choke points across different contexts and recommended actions to address the problems (stage 4).

\section{CASE STUDIES ON DETECTING SYSTEM CHOKE POINTS}

Our case studies (Fig. 4) come from the KnowSeas project and include examples with varying cultural, social, and economic conditions at different scales.

\section{Case study 1: Barra and cold water coral: conflict at the periphery of Europe}

The island of Barra, in the Outer Hebrides, off the northwest coast of Scotland, has a resident population of approximately 1200 people. A conflict erupted in 2008 over Scottish Natural Heritage's (SNH; a Scottish Government agency) proposal to designate a marine Special Area of Conservation (mSAC) to protect a cold water coral reef complex (Lophelia pertusa) in the waters east of Mingulay, an uninhabited island to the south of Barra. Despite resistance from the local community due to fears that the designation would impose limitations on development and impede existing uses such as fishing, the Minister for Environment and Climate Change approved the designation in 2011. The designation has been endorsed by the European Commission, and now has the status as a site of Community Importance, awaiting final designation by the Scottish Government. The formation in 2008 of a local action group SHAMED (Southern Hebrides Against Marine Environmental Designations) is evidence of the polarization in the conflict. The Chairman of SHAMED identified the social and economic wellbeing of the Barra community as being linked to local control over Barra's natural resources (Brennan and Valcic 2012). The fear of loss of control masks an underlying cultural and psychological choke point rooted in a suspicion of outsiders imposing changes and driven by differing perspectives of conservation practice. In this case, the administrations of Edinburgh (the Scottish Government) and Brussels (the EU Commission) represent entities removed from the local context who are perceived to exert control over the communities and the natural resources on which they depend. The cultural choke point is brought to the fore by the SAC designation process that exposes divergent perspectives on the management of local resources. The approach from the regulator was perceived as "locking up and protecting" the resource, whereas the community perceives 
Fig. 3. Soft system model for identifying and acting upon system choke points for achieving Good Environmental Status (GES; based on Checkland and Poulter 2006). The generic monitoring steps of this model are taken directly from examples in Checkland and Poulter (2006).

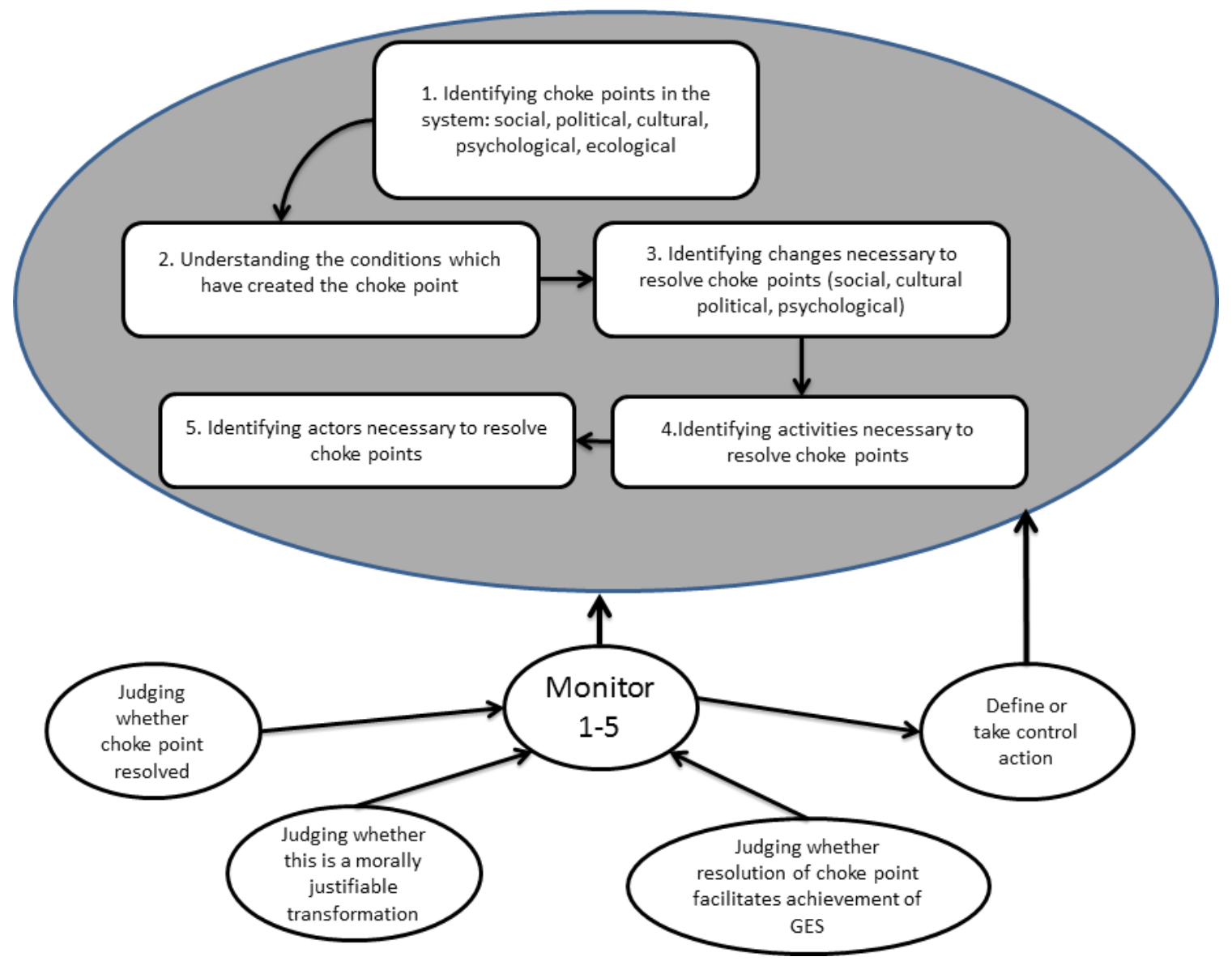

Fig. 4. Choke point case study regions.

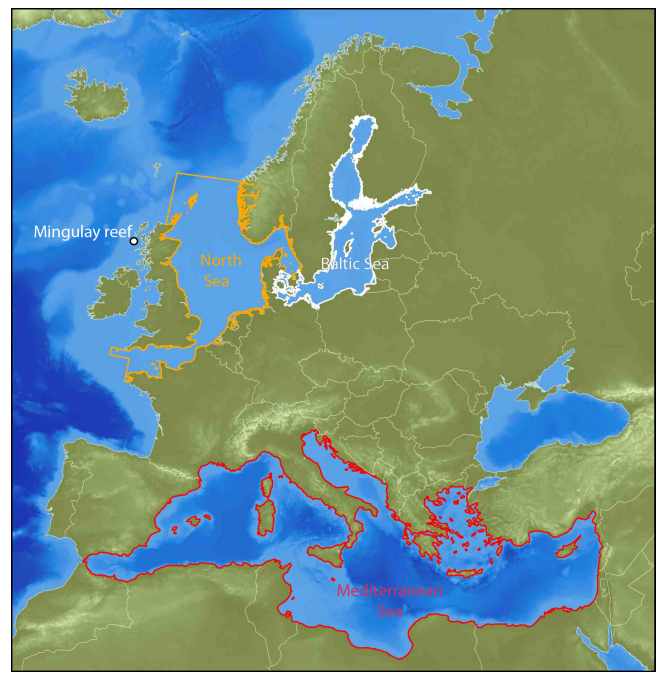

conservation as working with the sea and land within an ethic of stewardship. Recent cultural research into the dispute on Barra suggests that the sense of belonging to a home place and of responsibility for that place is key to understanding this choke point (MacKinnon and Brennan 2012). Many elements have created or exacerbated the conditions leading to this suspicion of outsiders imposing changes. To name a few:

- There is a history of the community being told what to do without being involved in the process, both in the conservation arena and in the history of the 19th-century Clearances, during which smallholder tenants were evicted or cleared off the land to make way for large sheep farms.

- While the designation of an SAC involves consulting with the community, the Habitats Directive (as interpreted by the European courts) only permits consultation on the scientific case for designation. SNH and the Scottish Government are not permitted to take social, economic, or cultural circumstances into account when deciding whether to propose (SNH) or designate (Scottish Minister) a site as an mSAC. This renders the consultation exercise ineffective at best and counter-productive at worst because it alienates the 
Table 1. European participation in Mediterranean marine governance.

\begin{tabular}{ll}
\hline \hline Type of management policy & List of relevant management policies \\
\hline $\begin{array}{l}\text { Management policies } \\
\text { concerning European marine } \\
\text { space }\end{array}$ & $\begin{array}{l}\text { EU environmental strategies; Strategy for the protection and conservation of the marine environment; Proposal } \\
\text { of European environmental strategy for the Mediterranean; funding instruments for environmental protection } \\
\text { (MEDSPA Programme/LIFE Programme) } \\
\text { European Territorial Strategy } \\
\text { Common coastal strategy } \\
\text { Integrated Maritime Policy; Integrated maritime policy for the Mediterranean } \\
\text { Common Fisheries Policy; Fishery regulations in Mediterranean waters; EU Action Plan for the conservation } \\
\text { and sustainable exploitation of fishery resources in the Mediterranean Sea }\end{array}$ \\
& $\begin{array}{l}\text { Participation in Mediterranean Action Plan and Barcelona Convention } \\
\text { Scientific projects in cooperation with third countries } \\
\text { Suro-Mediterranean } \\
\text { management policies }\end{array}$ \\
& $\begin{array}{l}\text { Cooperation in the field of underwater cultural heritage } \\
\text { Euro-Mediterranean environmental and fishery cooperation (Nicosia Charter, Cairo Declaration, Heraklion } \\
\text { Declaration) }\end{array}$ \\
\hline
\end{tabular}

community whose support is essential to the implementation of management of the site.

- Institutional and political rules can act as choke points. In this case, the prohibition on releasing Ministerial advice before the Minister has made a decision resulted in SNH not being permitted to release their consultation report to the local community, which deepened the suspicion surrounding the consultation. When the report was released and showed that local objections had been captured and reflected, the breakdown in communication had already become entrenched.

- As suspicion increased (based on local cultural choke points), locals became less willing to engage with the policy process, preferring to push it away as being a danger to the fabric of the Barra community by potentially restricting future developments of the marine resource and therefore reducing local job opportunities in the future.

- An inability on the part of the local community to articulate their understanding of conservation and their relationship with the marine environment increased the sense of not being listened to by SNH and the Scottish Government.

Resolving a choke point that is deeply embedded culturally and psychologically takes delicate work, part of which needs to come from within the community. In Barra, leaders need to emerge who are willing to engage with policy without being undermined by perceptions of betrayal from within the community. The worldviews of all parties need to be articulated within the context of a larger conservation picture (MacKinnon and Brennan 2012). Part of this articulation involves bringing a more complex human language into science as scientists and policy makers struggle with the task of dealing with the integrated social, economic, and ecological parts of an ecosystem (Brennan and Valcic 2012). Since July 2012, there has been dialog between a Marine Scotland official, the Minister for Environment and Climate Change, and locals within the community on community-led management of a different mSAC (located in the Sound of Barra, off the east coast of the island). This dialog, together with the appointment of the local organization Voluntary Action Barra and Vatersay to lead and facilitate the community-led management process, suggests that a significant shift in the social, cultural, political, and psychological choke points is occurring in relation to participatory natural resource management. However, the process is still at a very early stage, and sensitivities run deep (Brennan 2015).

Case study 2: Choke points in the Mediterranean: transboundary governance and geopolitics

Unlike in other regional seas, the European Union's presence in the Mediterranean, although significant, is partial, with one-third of coastal States and $36 \%$ of the basin's maritime surface area under European jurisdiction. With more States joining the EU, the institutional complexity of European seas will grow both in terms of internal coherence within the EU and engagement with non-EU States (Suárez de Vivero 2012). The mix of European and non-European jurisdictions is therefore a factor that complicates the delivery of GEnS (Cinnirella et al. 2014). Notwithstanding, the EU's political, economic, and technical weight gives it wide influence. These capabilities are nonetheless impaired by the considerable socioeconomic gap between EU and non-EU States, which undermines the effectiveness of management arrangements and the technical and political ability to achieve satisfactory levels of environmental quality. Table 1 shows the main channels through which the EU intervenes in the governance of the Mediterranean. These can, in turn, be considered as the mechanisms that need to be activated and strengthened to overcome the choke points and achieve the objective of GEnS.

Changes are being experienced in the Mediterranean Sea as a result of the political expansion of the EU. For example, with the negotiation of the Balkan states and the recent ascension of Croatia to the EU in 2013, substantial parts of the Adriatic coast are now covered by European law. The expansion of EU membership in the Mediterranean generally has a positive effect on achieving GEnS, without entering into the appreciable differences between each EU member's capacity to deliver the reforms. Expansion, however, also raises the challenge of institutional coordination and coherence with the institutions of the United Nations system such as the Mediterranean Action Plan (MAP) and the Barcelona Convention. The Convention provides a legal framework for protection of the marine 
environment of the Mediterranean and has similar goals to the MSFD concerning ecosystem-based management. Although a strong desire exists amongst Mediterranean coastal states to deepen cooperation, substantial obstacles exist in technical capacity, resources, and political commitments (UNEP 2012).

The question in the context of this paper is: How does Mediterranean marine governance relate to choke point identification? From one perspective, increasing European influence in the Mediterranean reduces the transboundary conflict that occurs within a complex system of bilateral or multilateral relations (Barbé 2010). Alternatively, it can lead to a situation in which GEnS progresses in parts of the region and deteriorates in others. This institutional choke point could potentially undermine the achievement of GEnS with issues that have a transboundary nature such as fisheries, climate change, and pollution management. In the Mediterranean, cooperation and negotiation among all coastal States will be a driver for achieving high levels of environmental quality.

Following Checkland and Poulter's (2006) approach to identifying actions, the complexity of the issues in the Mediterranean brings two points to attention. First, is the necessity for synergy between MSFD and the MAP strategy to ensure the achievement of GEnS, or "Healthy Environment" as defined in Mediterranean Action Plan (MAP). Second, MSFD implementation in the Mediterranean needs a governance approach for flexible and permanent interaction between institutions (Cinnirella et al. 2013, 2014), including:

- Effective synergies by aligning the UNEP-MAP vision of healthy ecosystems through GEnS descriptors that would be of obligation for EU countries and by enforcing international cooperation between EU Member States;

- Adoption of an innovative management approach to be able to deal with this transformation. Management should work under three main principles: adaptive, proactive, and transparent, to ensure the active participation of all stakeholders as well as their integration and coordination; and

- Adoption of new tools to help management processes (Sardá et al. 2010) and facilitate interoperable exchange of information (Cinnirella et al. 2012).

Given the vast political, cultural, and economic gulf between the northern and southern Mediterranean states, a unified approach to environmental governance is a major political challenge. The problems of capacity, low levels of economic prosperity, and functional democracy remain to be addressed. The environmental objectives from the MSFD and MAP will need to be integrated with each other and across other relevant policy domains, including agriculture, fisheries, and economic development, to ensure advances in marine environmental quality in the Mediterranean.

Case study 3: Baltic Sea welfare trade-offs: tackling nitrogen in the Baltic Sea

In the Baltic Sea, the Baltic Sea Action Plan and the MSFD set targets for the reduction of nutrient loads (Baltic Sea Action Plan 2007). It is estimated that to meet the targets, a reduction in nutrient input into Baltic Sea of $65 \%$ of the loadings in phosphorus $(\mathrm{P})$ and $29 \%$ in nitrogen $(\mathrm{N})$ in 2021 compared to average inputs for 1997-2003 is required (HELCOM 2007). There are 14 industrialized countries in the drainage basin of the Baltic Sea, and activities such as agriculture, industries, municipal sewage, river run-off, nitrogen fixation, and atmospheric deposition have added to the nutrient loads. The main sources for $\mathrm{N}$ and $\mathrm{P}$ discharges are agriculture $(59 \% \mathrm{~N}$ and $50 \% \mathrm{P})$, sewage $(12 \% \mathrm{~N}$ and $50 \% \mathrm{P})$, and for $\mathrm{N}, 29 \%$ is airborne from mobile sources (Gren et al. 2008). Gren et al. (2008) calculate that a costefficient reduction program would tally approximately $€ 4$ billion/ yr. Other studies such as that of Hyytiäinen et al. (2013) highlight that the benefits of nutrient reduction in the Baltic clearly outweigh the aggregate costs. Moreover, for reductions of $\mathrm{N}$ and $\mathrm{P}>20 \%$, the marginal reduction costs increase steeply. The largest share of reduction costs are borne by the farming industry. Moreover, the high costs associated with reducing the emissions ( $\mathrm{N}$ and $\mathrm{P}$ ) will not be borne by those who benefit from the cleaner water (changes in fish stocks, improved recreational use, and health; Vesterinen et al. 2010, Luisetti and Turner 2011, Varjopuro et al. 2014).

This case demonstrates that ecological choke points must be considered alongside institutional and political choke points. Characteristics of $\mathrm{N}$ and $\mathrm{P}$ reduction in the Baltic Sea are ecosystem delays with reduction of fertilizer use not resulting in immediate reduction of nutrient emissions and delays in ecosystem responses with internal loading. The time from changes in pressures to changes in state can take decades. The causes for delay are the slow renewal of water masses, strong stratification, small water volume, and large river runoff in the Baltic. As pollution targets are implemented, the costs of meeting targets will raise the costs for the farming industry and could generate economic and political choke points. In the interaction between economic and ecological choke points (Fig. 5), initial high costs of nutrient reduction yield little short- to medium-term benefit (the first evaluation) because of ecosystem delays. The outcome is that indicators for GEnS will not show improvement in the short term despite management costs being relatively high. This increases the tension in the governance system and could potentially fuel conflict between stakeholder groups due to the low visibility of benefits vs. the high visibility of costs. This choke point could undermine the long-term management that is required to improve the system over time.

Fig. 5. Development of costs and effect of policy on Good Environmental Status.

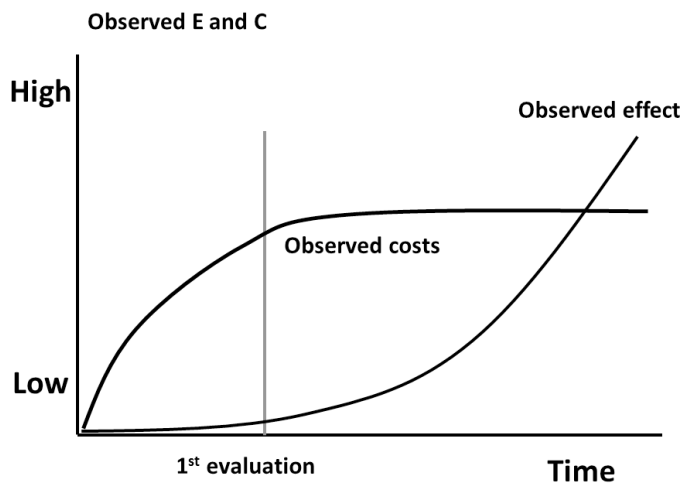


This phenomenon could undermine the implementation of GEnS or alternatively affect the value of agricultural products and the viability of the sector. The outcome may be that as polices for managing eutrophication become more costly and the monitoring may not show significant improvement, the acceptance of the policy by stakeholder groups might change. This could reinforce a political choke point where the process becomes polarized. As environmental progress is delayed (potentially due to the cost vs. benefits; Fig. 5), social and political polarizations could emerge (Fig. 6). A likely consequence in a system that is not showing progress, due to ecological and physical choke points, is that certain groups would lobby for more stringent measures, i.e., claiming that the current measures are not sufficient, while the group bearing the costs would lobby for the delay of reduction actions because of the uncertainly over the system's response. The policy process approaches a choke point where the interests over policy action are divergent (as in case study 1). The workshop discussions emphasized the key role of science in providing independent and impartial knowledge to support consensus over maintaining the GEnS target despite the lags and delays in the ecological system.

Fig. 6. Polarization of interest group demands. ALG = agricultural lobby group; $\mathrm{EG}=$ environmental group.

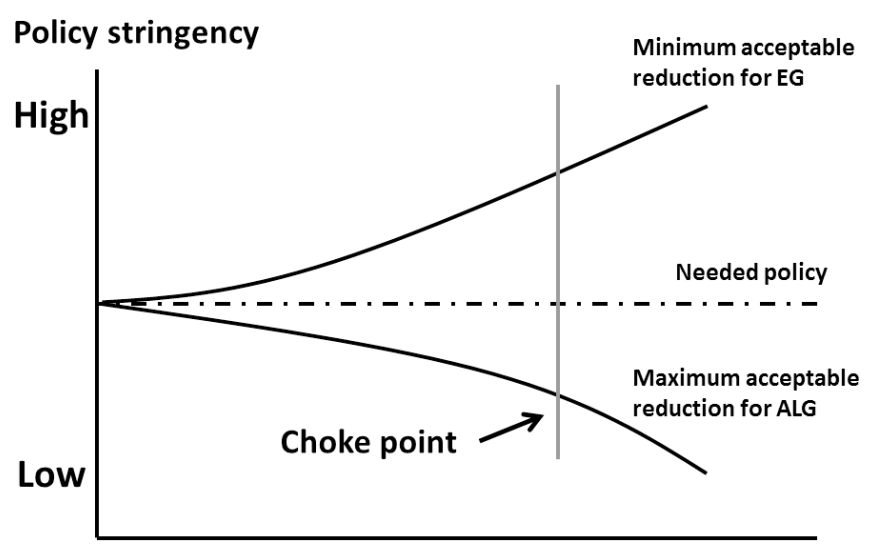

Time

Case study 4: Differing values, managing transboundary nutrients Since the early 1980s, eutrophication has been one of the major issues in the North Sea (Brockmann et al. 1988, de Jonge and Essink 1991, van Beusekom et al. 2001). This issue results from nutrient inputs discharged via rivers. Though river loads have been substantially reduced since 1985 (e.g., Radach and Pätsch 2007), eutrophication is still a problem in large areas along the North Sea coast (OSPAR 2010). Eutrophication leads to a number of problems, including algal blooms and sedimentation resulting in oxygen depletion (e.g., von Westernhagen et al. 1986). Because of the proximity to nutrient sources, coastal areas are prone to eutrophication problems. For example, in the Wadden Sea, eutrophication symptoms include the disappearance of seagrass (e.g., Kastler and Michaelis 1997), proliferation of opportunistic macroalgae (Reise and Siebert 1994), and increased flagellate blooms (Cadée and Hegeman 2002).
A complication in combating eutrophication is that nutrients are transported across boundaries. This occurs within transboundary river systems (such as the Rhine) and coastal zones. To reduce eutrophication in one country and its coastal waters, it may be necessary to reduce river loads in another country. This requires transnational cooperation addressing institutional, administrative, and political choke points at the regional sea scale. Two European Directives are in place to reach Good Ecological/Environmental Status, the MSFD and the Water Framework Directive (WFD). The philosophy behind the WFD is that the status of entire river basins is assessed. In the case of the Wadden Sea, the coastal water bodies are formally part of a river basin. However, the Wadden Sea is also affected by large amounts of organic matter imported from the North Sea (van Beusekom et al. 2012). The situation is complicated further by so-called transboundary transports of nutrients; nutrients from the Rhine are a significant source off the German coast (e.g., Beddig et al. 1997). Given this background, several choke points to reach GEnS with regard to eutrophication can be identified.

- Harmonization of ambitions and definitions: Because of the issue of transboundary nutrient transport, countries cannot successfully combat eutrophication on their own. A successful strategy starts with achieving consensus on the definition of GEnS. This involves comparable political willingness to strive for good water quality. Regional political differences, limited resources, and different priorities may hamper consensus. However, even if ambitions are harmonized, defining targets may be a challenge. For example, the current thresholds for eutrophication parameters are defined on the basis of background concentrations. Because countries may assume different background concentrations, two adjacent regions with similar concentrations can have a different environmental status.

- Harmonization of measures: Combating eutrophication requires transnational agreement. This means that countries should be willing to reduce river loads in their country even if the rivers (and nutrients) involved do not end up in their own marine areas. A more contentious example is when countries need to agree to go for the most cost-effective solution, in which case one country could pay for reduction measures in another country, if those are less costly and more effective.

- Goals and measures fall under different legislation (WFD, MSFD): Reducing river nutrient loads falls under the WFD, whereas achieving GEnS in marine areas falls under the MSFD. To make things even more complicated, goals have been set for coastal areas both by the WFD and the MSFD. All of this requires a large degree of harmonization between the two legal frameworks. This is an even greater challenge than achieving harmonization within one legal framework, as it involves more stakeholders, including the agricultural sector, sewage/water treatment plants, and governmental and nongovernmental organizations, all with different and sometimes conflicting interests. The major source responsible for present nutrient fluxes is agriculture (e.g., Aertebjerg et al. 2003). Consequently, any EU policies concerning agriculture (such as the Common Agricultural Policy) will affect water quality. 
Table 2. Choke points identified in the case studies, and generic examples.

\begin{tabular}{|c|c|c|}
\hline Choke point category & Case study examples & Generic examples from environmental governance \\
\hline Cultural & $\begin{array}{l}\text { Values conflict (case } 1,3) \\
\text { Historical conflicts (case 1,2) }\end{array}$ & $\begin{array}{l}\text { Social perceptions of the environment } \\
\text { Conflicts between cultural groups } \\
\text { Different epistemologies (e.g., science and } \\
\text { traditional knolwedge) }\end{array}$ \\
\hline Psychological & $\begin{array}{l}\text { Sense of historical inequity (case 1) } \\
\text { Communication with remote governments (case 1) }\end{array}$ & $\begin{array}{l}\text { Value-behavior gap } \\
\text { Individual perceptions of the enviornment } \\
\text { Pro-environmental behaviors }\end{array}$ \\
\hline Political & $\begin{array}{l}\text { Differences in political economy in relation to Good } \\
\text { Environmental Status (case 2, 4) } \\
\text { International relations (case 2,3) } \\
\text { Clash of international governance regimes (case 2,4) } \\
\text { Conflict over Good Environmental Status objectives between } \\
\text { sectors (case 3) }\end{array}$ & $\begin{array}{l}\text { Political interia } \\
\text { Political views within and between governments } \\
\text { Environmental justice and conflict }\end{array}$ \\
\hline Institutional & $\begin{array}{l}\text { Mismatching governance scales (case 1,2) } \\
\text { Poorly designed consultation processes (case 1) } \\
\text { Institutional processes (case 1, 3) } \\
\text { Transboundary policy alignment (case 2, 4) } \\
\text { Mismatch of technical capacity and standards (case 2, 4) } \\
\text { Science-policy gap (case 3) } \\
\text { Integration between European Union policy, e.g., Water } \\
\text { Framework Directive and Marine Strategy Framework } \\
\text { Directive (case 4) }\end{array}$ & $\begin{array}{l}\text { Policy fragmentation within and between } \\
\text { government } \\
\text { Policy life cycles } \\
\text { Science and policy mismatches }\end{array}$ \\
\hline Ecological & $\begin{array}{l}\text { Nutrient cycling processes (case } 3,4 \text { ) } \\
\text { Nonlinear system responses (case } 3 \text { ) }\end{array}$ & $\begin{array}{l}\text { Carbon cycle } \\
\text { Ecological responses to policy and management }\end{array}$ \\
\hline
\end{tabular}

To summarize, the major choke points hindering the achievement of GEnS with regard to eutrophication are agricultural policies and international consensus on standards. Without an agreement between different European Commission Directorates and between countries on common definitions and integration between agriculture, energy, and environmental policy, it will be difficult to reach GEnS targets for eutrophication problems.

\section{CONCLUSION: HOW DO WE IDENTIFY CHOKE POINTS?}

Identifying choke points is a broader part of a systems approach to understanding social-ecological systems. It is a starting point for action on resolving environmental problems that have underlying political, institutional, and social barriers. The choke point analogy is not only relevant for marine governance; it applies to a number of sustainability domains, including biodiversity conservation, climate change, and natural resource management. The principal underlying choke point identification is the analysis of blockages in a system using a systems-based and collaborative approach. Identification then facilitates action on resolving these blockages. Actions are iterated in a regular cycle to track progress, learn, and adapt to systems that are constantly changing. In the examples above, be it cultural issues in the western isles of Scotland, the transnational politics of the Mediterranean, or pollution reduction, a long-term commitment to support systems thinking and engagement between science, policy, and civil society is required. The process is one of learning and adaptation that examines the evolving status of the choke point and adjusts the response. For example, the actors supporting the choke point may have altered their perspectives, the underlying political conditions may have changed, or the choke point may have been resolved.
SSM provides a useful method for assessing choke points in light of its multidisciplinary approach to model building and emphasis on social learning. However, other participatory methods could be used to identify and act upon choke points. These include, but are not limited to, methods such as citizen juries, participatory conceptual modeling, focus groups, interviews, and case studies. The point is that a systemic and transparent process is developed that determines the social, cultural, political, institutional, or psychological choke points and develops consensual and adaptive means of their resolution. Several generic classes of choke points can be identified through the case studies (Table 2), providing examples that may emerge from explorations using SSM or similar methods. They are clearly not exhaustive, but do highlight issues of differing values or worldviews and political and institutional contexts. At a local level, on the island of Barra, the psychology of historical inequity has manifested in objections to a Special Area of Conservation whose implementation may not restrict activities in practice. Nevertheless, the psychological and cultural choke point remains, and this phenomenon is likely to recur as marine planning interacts with peripheral communities reliant on marine resources. In the Mediterranean, more tangible issues of inequity embedded in economic and political factors between the global North and South undermine EU environmental strategy. Any serious region-wide efforts to strengthen cooperation around GEnS through existing institutions are likely to encounter this choke point. It may also provide a focus for technological transfer and engagement with the southern Mediterranean countries to improve environmental quality. The two eutrophication studies illustrate differing sets of values. In the Baltic case, the conflicting values are those of environmental groups and agricultural stakeholders within a system that is bounded by ecological choke points, i.e., long-term nutrient cycling. In the North Sea, both 
cultural and political values differ among nations and can provide an obstruction to progress on eutrophication. This case demonstrates a long-standing choke point in environmental governance: that of policy coordination across national jurisdictions (Potts et al. 2012).

We began by alluding to the notion of choke points as physical constraints. Of the typologies explored here, the closest analogy in marine governance is the ecological choke point identified in the Baltic case. However, the dominant form of choke point typology is from the social realm: that of the political, institutional, cultural, and psychological, reflecting the inherent social nature of environmental problems. These choke points are persistent in the discourse around the ecosystem approach and require a different set of tools to the traditional technocratic response to environmental problems. Exploring and resolving these types of choke point require an approach whereby a space for rational "communicative action" (Habermas 1984) is created to develop an understanding of different interests and viewpoints. Tett et al. (2012) explore this dynamic and note the tensions between communicative action, in which stakeholder understanding is increased, and strategic action, in which individuals and institutions strive to advance their interests. The current situation in European regional seas governance appears aligned to the latter, with competitive interests bargaining over marine resources. If the ecosystem approach is to be realized, government and civil society will need to develop mechanisms to advance communicative action that address the choke points that constrain advancement toward healthy oceans.

\section{Responses to this article can be read online at:}

http://www.ecologyandsociety.org/issues/responses. $\mathrm{php} / 7280$

\section{Acknowledgments:}

We thank the EU FP7 Know Seas project for supporting the research that led to the development of this paper. We also note the tragic recent passing of Professor Laurence Mee, Director of the Scottish Association for Marine Science, who led the KnowSeas project and inspired many people over the conservation of the oceans.

\section{LITERATURE CITED}

Ærtebjerg, G., J. H. Andersen, and O. S. Hansen, editors. 2003. Nutrients and eutrophication in Danish marine waters: a challenge for science and management. National Environmental Research Institute, Danish Ministry of the Environment, Copenhagen, Denmark. [online] URL: http://www2.dmu.dk/1 Viden/2 Publikationer/3 ovrige/rapporter/Nedmw2003 alle.pdf.

Bainbridge, J. M., T. Potts, T. G. O’Higgins. 2011. Rapid policy network mapping: a new method for understanding governance structures for implementation of marine environmental policy. PLoS One 6(10): e26149. http://dx.doi.org/10.1371/journal. pone.0026149

Baltic Sea Action Plan. 2007. An approach to set country-wise nutrient reduction allocations to reach good marine environment of the Baltic Sea. Helcom BSAP Eutro Expo/2007, Helsinki Commission, Helsinki, Finland.
Barbé, E. 2010. La Unión Europea más allá de sus fronteras: hacia la transformación del Mediterráneo y Europa Oriental? Tecnos, Madrid, Spain.

Beddig, S., U. Brockmann, W. Dannecker, D. Körner, T. Pohlmann, and W. Puls, G. Radach, A. Rebers, H.-J. Rick, M. Schatzmann, H. Schlünzen, and M. Schulz. 1997. Nitrogen fluxes in the German Bight. Marine Pollution Bulletin 34(6):382-394. http://dx.doi.org/10.1016/S0025-326X(96)00159-2

Brennan, R. E. 2015. What lies beneath: probing the cultural depths of a nature conservation conflict in the Outer Hebrides. Dissertation. University of the Highlands and Islands, Oban, UK.

Brennan, R. E., and B. Valcic. 2012. Shifting perspectives - How the masks we wear can facilitate and inhibit channels of communication in the social-environmental policy context. Ocean and Coastal Management 62:1-8. http://dx.doi.org/10.1016/j. ocecoaman.2012.02.004

Brockmann, U., G. Billen, and W. W. C. Gieskes. 1988. North Sea nutrients and eutrophication. Pages 348-389 in W. Salomons, B. L. Bayne, E. K. Duursma, and U. Förstner, editors. Pollution of the North Sea, an assessment. Springer-Verlag, Berlin, Germany. http://dx.doi.org/10.1007/978-3-642-73709-1_20

Cadée, G. C., and J. Hegeman. 2002. Phytoplankton in the Marsdiep at the end of the 20th century; 30 years monitoring biomass, primary production, and Phaeocystis blooms. Journal of Sea Research 48(2):97-110. http://dx.doi.org/10.1016/ $\underline{\text { S1385-1101(02)00161-2 }}$

Checkland, P., and J. Poulter. 2006. Learnng for action: a short definitive account of soft systems methodology and its use for practitioners, teachers, and students. Wiley, West Sussex, UK.

Checkland, P., and J. Poulter. 2010. Soft systems methodology. Pages 191-242 in M. Reynolds and S. Holwell, editors. Systems approaches to managing change: a practical guide. Springer and The Open University, London, UK.

Cinnirella, S., M. Graziano, J. Pon, C. Murciano, J. Albaigés, and N. Pirrone. 2013. Integrated assessment of chemical pollution in the Mediterranean Sea: driver-pressures-State-welfare analysis. Ocean and Coastal Management 80:36-45. http://dx.doi. org/10.1016/j.ocecoaman.2013.02.022

Cinnirella, S., D. March, T. O’Higgins, C. Murciano, R. Sardà, J. Albaigés, and N. Pirrone. 2012. A multidisciplinary spatial data infrastructure for the Mediterranean to support the implementation of the Marine Strategy Framework Directive. International Journal of Spatial Data Infrastructure Research 7:323-351. http://dx.doi.org/10.2902/1725-0463.2012.07.art16

Cinnirella, S., R. Sardà, J. L. Suárez de Vivero, R. Brennan, A. Barausse, J. Icely, T. Luisetti, D. March, C. Murciano, A. Newton, T. O'Higgins, L. Palmeri, M. G. Palmieri, P. Raux, S. Rees, J. Albaiges, N. Pirrone, and K. Turner. 2014. Steps toward a shared governance response for achieving Good Environmental Status in the Mediterranean Sea. Ecology and Society 19(4): 47. http:// dx.doi.org/10.5751/ES-07065-190447

Cundill, G., G. S. Cumming, D. Biggs, and C. Fabricius. 2012. Soft systems thinking and social learning for adaptive management. Conservation Biology 26(1):13-20. http://dx.doi. org/10.1111/j.1523-1739.2011.01755.x 
de Jonge, V. N., and K. Essink. 1991. Long-term changes in nutrient loads and primary and secondary production in the Dutch Wadden Sea. Pages 307-316 in M. Elliot and J.-P. Ducrotoy, editors. Estuaries and coasts: spatial and temporal intercomparisons. Olsen and Olsen, Fredensborg, Denmark.

Emmerson, C., and P. Stevens. 2012. Maritime choke points and the global energy system: charting a way forward. Chatham House Briefing Paper. Royal Institute of International Affairs, London, UK. [online] URL: http://www.chathamhouse.org/sites/default/ files/public/Research/Energy, $\% 20$ Environment $\% 20$ and $\% 20$ Development/ bp0112 emmerson stevens.pdf.

European Parliament. 2008. Directive 2008/56/EC of the European Parliament and of the Council of 17 June 2008 establishing a framework for community action in the field of marine environmental policy (Marine Strategy Framework Directive). European Parliament, Strasbourg, France.

Flood, R. L. 2010. The relationship of 'systems thinking' to action research. Systematic Practice and Action Research 23(4):269-284. http://dx.doi.org/10.1007/s11213-010-9169-1

Gren, I.-M., Y. Jonzon, and M. Lindqvist. 2008. Costs of nutrient reductions to the Baltic Sea: technical report. Working Paper Series 2008:1. Swedish University of Agricultural Sciences, Uppsala, Sweden. [online] URL: http://pub.epsilon.slu.se/3212/1/ Cost_of nutrient_reductionsWPfinal.pdf.

Habermas, J. 1984. The theory of communicative action. Volume 1: reason and the rationalization of society. Translated by $\mathrm{T}$. McCarthy. Beacon Press, Boston, Massachusetts, USA.

HELCOM. 2007 Climate change in the Baltic Sea area: HELCOM thematic assessment in 2007. Baltic Sea Environmental Protection 111. Helsinki Commission, Helsinki, Finland.

Hyytiäinen, K., B. Hasler, S. Ericsdotter, M. Nekoro, K. Blyh, J. Artell, L. Ahlvik, and H. Ahtiainen. 2013. Worth it: benefits outweigh costs in reducing eutrophication in the Baltic. BalticSTERN Summary Report for HELCOM 2013 Ministerial Meeting. Helsinki Commission, Helsinki, Finland. [online] URL: http://helcom.fi/Documents/Ministerial2013/Associated\%20documents/ Background/BalticSternReport.pdf.

Jentoft, S., and R. Chuenpagdee. 2009. Fisheries and coastal governance as a wicked problem. Marine Policy 33(4):553-560. http://dx.doi.org/10.1016/j.marpol.2008.12.002

Kasimin, H., and M. Yusoff. 1996. The use of a soft systems approach in developing information systems for development planning: an exploration in regional planning. Computers, Environment and Urban Systems 20(3):165-180. http://dx.doi. org/10.1016/S0198-9715(96)00012-9

Kastler, T., and H. Michaelis. 1997. The declining segrass beds in the Wadden Sea area of Niedersachsen. Bericht Forschungsstelle Küste 41:119-139.

Long, R. 2011 The Marine Strategy Framework Directive: a new European approach to the regulation of the marine environment, marine natural resources and marine ecological services. Journal of Energy and Natural Resources Law 29(1):1-44.

Luisetti, T., and K. Turner 2011. KnowSeas deliverable 4.2. How water quality affects European coastal and marine recreation: a benefit transfer exercise to value health effects and eutrophication at regional sea level. UEA, East Anglia, UK.

MacKinnon, I., and R. Brennan. 2012. Dùthchas na maral belonging to the sea. Exploring the cultural roots of maritime conflict on Gaelic speaking islands in Ireland and Scotland. Scottish Crofting Association, Kyle of Lochalsh, UK. [online] URL: http://www.sams.ac.uk/ruth-brennan/belonging-to-the-sea.

Mee, L. D., R. L. Jefferson, D. d'A. Laffoley, and M. Elliott. 2008. How good is good? Human values and Europe's proposed Marine Strategy Directive. Marine Pollution Bulletin 56(2):187-204. http://dx.doi.org/10.1016/j.marpolbul.2007.09.038

Ngai, E. W. T., C. K. M. To, V. S. M. Ching, L. K. Chan, M. C. M. Lee, Y. S. Choi, and P. Y. F. Chai. 2012. Development of the conceptual model of energy and utility management in textile processing: a soft systems approach. International Journal of Production Economics 135(2):607-617. http://dx.doi.org/10.1016/ j.ijpe.2011.05.016

Noer, J. H., and D. Gregory. 1996. Chokepoints: maritime economic concerns in Southeast Asia. NDU Press, National Defence University: Institute for National Strategic Studies, Washington, D.C., USA.

OSPAR. 2010. Quality status report 2010. OSPAR Commission, London, UK. [online] URL: http://qsr2010.ospar.org/en/index. html.

Potts, T., T. O'Higgins, and E. Hastings. 2012. Oceans of opportunity or rough seas? What does the future hold for developments in European marine policy? Philosophical Transitions of the Royal Society A 370:5682-5700. http://dx.doi. org/10.1098/rsta.2012.0394

Radach, G., and J. Pätsch. 2007. Variability of continental riverine freshwater and nutrient inputs into the North Sea for the years 1977-2000 and its consequences for the assessment of eutrophication. Estuaries and Coasts 30(1):66-81. http://dx.doi. org/10.1007/BF02782968

Reise, K., and I. Siebert. 1994. Mass occurrence of green algae in the German Wadden Sea. Deutsche Hydrographische Zeitschrift 1:171-188.

Roger, W. 2012. An introduction to choke points. EnergyTrends Insider May 21. [online] ULR: http://www.energytrendsinsider. com/2012/05/21/an-introduction-to-choke-points/.

Sardà, R., A. Diedrich, J. Tintoré, and R. Cormier. 2010. The ecosystem-based management system: a formal tool for the management of the marine environment. Littoral 2010, 14001. EDP Sciences, Les Ulis, France. [online] URL: http://coastnetlittoral2010.edpsciences.org/articles/litt/pdf/2011/01/litt-14001.pdf.

Smith, L. D., R. M. Nauss, D. C. Mattfeld, J. Li, J. F. Ehmke, and M. Reind1. 2011. Scheduling operations at system choke points with sequence-dependent delays and processing times. Transportation Research Part E 47(5):669-680. http://dx.doi. org/10.1016/j.tre.2011.02.005

Sørensen, C. G., S. Fountas, E. Nash, L. Pesonen, D. Bochtis, S. M. Pedersen, B. Basso, and S. B. Blackmore. 2010. Conceptual model of a future farm management information system. Computers and Electronics in Agriculture 72(1):37-47. http://dx. doi.org/10.1016/j.compag.2010.02.003 
Suárez De Vivero, J. L. 2012. Fisheries cooperation in the Mediterranean and the Black Sea. European Parliament, Directorate-General for Internal Policies, Brussels, Belgium.

Tett, P., B. Valcic, T. Potts, C. Whyte, F. Culhane, and T. Fernandes. 2012. Mussels and yachts in Loch Fyne, Scotland: a case study of the science-policy interface. Ecology and Society 17(3): 16. http://dx.doi.org/10.5751/ES-04995-170316

UNEP [United Nations Environment Programme]. 2012. Implementation of the ecosystem approach (EcAp) in the Mediterranean by the Contracting parties in the context of the Barcelona Convention for the Protection of the Marine Environment and the Coastal region of the Mediterranean and its Protocols. UNEP, Nairobi, Kenya. [online] URL: http://ec. europa.eu/environment/marine/pdf/Implementation EcAp.pdf.

van Beusekom, J. E. E., C. Buschbaum, and K. Reise. 2012. Wadden Sea tidal basins and the mediating role of the North Sea in ecological processes: scaling up of management? Ocean and Coastal Management 68:69-78. http://dx.doi.org/10.1016/j. ocecoaman.2012.05.002

van Beusekom, J. E. E., H. Fock, F. de Jong, S. Diel-Christiansen, and B. Christiansen. 2001. Wadden Sea specific eutrophication criteria. Wadden Sea Ecosystem 14. Common Wadden Sea Secretariat, Wilhelmshaven, Germany. [online] URL: http://www. waddensea-secretariat.org/management/publications/wadden-seaspecific-eutrophication-criteria-2001.

Varjopuro, R., E. Andrulewicz, T. Blenckner, T. Dolch, A.-S. Heiskanen, M. Pihlajamäki, U. Steiner Brandt, M. Valman, K. Gee, T. Potts, and I. Psuty. 2014. Coping with persistent environmental problems: systemic delays in reducing eutrophication of the Baltic Sea. Ecology and Society 19(4): 48. http://dx.doi.org/10.5751/ES-06938-190448

Vesterinen, J., E. Pouta, A. Huhtala, and M. Neuvonen. 2010. Impacts of changes in water quality on recreation behavior and benefits in Finland. Journal of Environmental Management 91 (4):984-994. http://dx.doi.org/10.1016/j.jenvman.2009.12.005

von Westernhagen, H., W. Hickel, E. Bauerfeind, U. Niermann, and I. Kröncke. 1986. Sources and effects of oxygen deficiencies in the south-eastern North Sea. Ophelia 26(1):457-473. http://dx. doi.org/10.1080/00785326.1986.10422006 